International Journal of Instruction e-ISSN: 1308-1470 • www.e-iji.net

Article submission code: 20191110033024

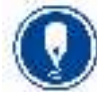

January $2021 \bullet$ Vol.14, No.1

p-ISSN: 1694-609X

pp. $847-866$

Received: 10/11/2019

Revision: 05/08/2020
Accepted: 26/08/2020

OnlineFirst:28/11/2020

\title{
Dominant Factors that Cause Students' Difficulties in Learning Abstract Algebra: A Case Study at a University in Indonesia
}

\section{Nina Agustyaningrum}

Universitas Riau Kepulauan, Indonesia, nina@fkip.unrika.ac.id

\section{Riska Novia Sari}

Corresponding author, Universitas Pasir Pengaraian, Indonesia, riskanoviasari@upp.ac.id

\section{Agus Maman Abadi}

Dr., Universitas Negeri Yogyakarta, Indonesia, agusmaman@uny.ac.id

\section{Ali Mahmudi}

Dr., Universitas Negeri Yogyakarta, Indonesia, alimahmudi@uny.ac.id

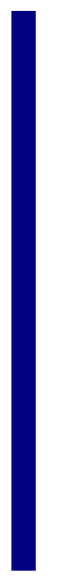

This study aims to find out the dominant factors that cause students' difficulties in learning abstract algebra. The factors investigated in this study focused on attitude, motivation, prior knowledge, lecturer performance, learning methods, as well as teaching materials. This study is a descriptive research using a survey method. We involved 30 students of mathematics education department in Riau Kepulauan University, Indonesia. To get the data, we used questionnaire and interview. Based on the questionnaire result analysis, there were three dominant factors causing the students' difficulties in learning abstract algebra. They were students' attitudes towards abstract algebra, prior knowledge, and teaching materials with the percentage of $36.7 \%, 28.4 \%$, and $23.4 \%$ respectively (strong category). Meanwhile, the other three factors - motivation, lecturer performance, and learning method - had the percentage of $45.4 \%, 56.7 \%$, and $43.4 \%$ respectively (fair category). These results impact on the finding of dominant factors causing the difficulties in learning abstract algebra. At the end, it could be a reference for the lecturer to improve the learning effectiveness.

Keywords: abstract algebra, learning difficulties, attitudes, prior knowledge, teaching

\section{INTRODUCTION}

Abstract algebra has been widely recognized as an essential element of mathematics courses (Clark, 1984; Weber \& Larsen, 2008; Fadilah \& Jamilah, 2016). Many parties agreed that the axiomatic method provides the most beneficial and efficient technique within the learning process. As mentioned by Findell (2001) that abstract algebra consists of axiomatic theories that provide opportunities to consider many different

Citation: Agustyaningrun, N., Sari, R. N., Abadi, A. M., \& Mahmudi, A. (2021). Dominant Factors that Cause Students' Difficulties in Learning Abstract Algebra: A Case Study at a University in Indonesia. International Journal of Instruction, 14(1), 847-866. https://doi.org/10.29333/iji.2021.14151a 
mathematical systems as a special case of the same abstract structure. The theories are called axiomatic because axioms define the structures, and group theory as one of the oldest (and the simplest) of axiomatic theories. An abstract algebra courses plays a role where students might extract standard features from many mathematical systems that have been used in their previous mathematics courses, such as calculus, linear algebra, and algebra. They also have opportunities to develop deeper understandings of concepts, such as identity, inverse, equivalence, and function.

Furthermore, the advance of science and computation makes the abstract algebra more applicable, not only in mathematics but also computer science, physics, chemistry, data communications, coding theory application, and cryptography (Gallian, 2010; Judson, 2015). Professional organizations and educational institutions have agreed that abstract algebra is an essential part of prospective mathematics teachers (Findell, 2001).

Many students, however, find difficulties in learning abstract algebra. Weber (2002) shows the students' low ability to prove theorems, especially about homomorphism. Also, Arikan, Ozkan, \& Ozkan (2015) found that students experienced difficulties in understanding group theory, whereas this understanding is important as the basic to learn the more advance material, for instance, the ring and field.

Similar conditions occured in various universities in Indonesia. Listiawati (2015) from STKIP PGRI Bangkalan found that students did not understand the group concept that impacts the low score of students' mid-term exams of which $53 \%$ of students in one class got the score between 0 to 60 and none attained $80-100(0 \%)$. Besides, Yuniati (2014) also declared that the students' ability to solve algebraic structure problems was still unsatisfactory; they were confused to relate the information to make proof of problems. Moreover, Fadillah \& Jamilah (2015) from IKIP PGRI Pontianak reveal that algebra courses considered as difficult subjects among students caused by several factors, i.e. 1) abstract concepts of algebraic structure; 2) many unfamiliar concepts for students; 3) unfamiliar concept of deductive proof. Haryono \& Susanto's (2013) reported similar thing where $70 \%$ of students still regard the course of the algebraic structure as a complicated subject due to the nature of abstract algebraic material.

We, as lecturers of abstract algebra courses in the last three years at the Riau Kepulauan University, also encounter the same issue in which many students who get low grades as presented in Table 1 .

Table 1

The final semester examination scores in abstract algebra courses among the Students of Mathematics Education Department of Riau Kepulauan University in 2016 - 2018

\begin{tabular}{lllllll}
\hline $\begin{array}{l}\text { Score } \\
\text { Interval }\end{array}$ & Academic Year 2016/2017 & Academic Year 2017/2018 & $\begin{array}{l}\text { Academic } \\
2018 / 2019\end{array}$ & Year \\
\hline & $\begin{array}{l}\text { Students } \\
\text { Number }\end{array}$ & $\begin{array}{l}\text { Percentage } \\
(\%)\end{array}$ & $\begin{array}{l}\text { Students } \\
\text { Number }\end{array}$ & $\begin{array}{l}\text { Percentage } \\
(\%)\end{array}$ & $\begin{array}{l}\text { Students } \\
\text { Number }\end{array}$ & $\begin{array}{l}\text { Percentage } \\
(\%)\end{array}$ \\
\hline $\mathrm{A} \geq 81$ & 10 & 11.6 & 11 & 20.7 & 0 & 0 \\
\hline $68 \leq \mathrm{B}<81$ & 31 & 36 & 8 & 15.1 & 5 & 16.67 \\
\hline $56 \leq \mathrm{C}<68$ & 18 & 21 & 9 & 17 & 8 & 26.67 \\
\hline $\mathrm{D}<56$ & 27 & 31.4 & 25 & 47.2 & 17 & 56.67 \\
\hline Total & 86 & 100 & 53 & 100 & 30 & 100 \\
\hline
\end{tabular}


Based on Table 1, it can be seen that the percentage of student achievement in abstract algebra is still unsatisfactory from 2016 to 2018 of which the biggest percentage is in the intervals of $\mathrm{C}$ and D. It encourages researchers to investigate the causes of student difficulties in learning abstract algebra. In 2018, researchers have examined the types of students' errors in solving abstract algebra problems that are dominated by group material. As a result, most students' errors are in the area of concept errors, followed by careless errors, and computational errors. From 31 research subjects, all of them made mistakes in solving the exercises and none can solve all the question items without committing errors. It shows that abstract algebra courses are still becoming a problem for most students (Agustyaningrum et al, 2018). Besides, we also found that the students' ability in mathematical proving and problem solving of abstract algebra was still under performance (Agustyaningrum et al, 2019; Agustyaningrum et al, 2020). It reflected the students' difficulties in learning abstract algebra.

Considering this phenomenon, appropriate action should be done to overcome this problem. To formulate the right solution, the factors affecting the students' difficulties in learning abstract algebra must be certainly clarified. Knowing the students' difficulties in mathematics subject can help them through their learning process (Karimah, Kusmayadi, \& Pramudya, 2018). This explanation indicates the importance to analyze the factor causing students' learning difficulties to decide appropriate strategies to overcome the problem of abstract algebra courses. Those factors can be the foundation for the lecturers to develop appropriate strategies to improve students' learning outcomes.

Mundia (2012) stated that in the developing countries, many students from the entire education level experience some difficulties to study Mathematics and these difficulties factors are plentiful and varied. For example, the study from Ikramuddin \& Quraisy (2017) suggested that the factors affecting students' learning difficulties in learning abstract algebra including two intrinsic factors, namely physical and psychological. Meanwhile, extrinsic factors include lecturer factors, material content, tools, facilities as well as environmental elements from both campus and community environment. Other extrinsic factors are the role of parents and family environment. Furthermore, Syah (2010) divided the factors causing learning difficulties into two types, namely internal factors including (1) cognitive, (2) affective, (3) psychomotor, and external factors, such as (1) family environment, (2) community environment, (3) school environment. Gafoor $\&$ Kurukkan (2015) also stated the contribution factors including cognitive, affective, and environmental aspects.

Briefly, Saputra, Subagsono, \& Rohman (2012) categorized the factors causing students learning difficulties into two main aspects, internal and external factors. The internal factors contain physiological factors (physical condition and physical function condition) and psychological factors (intelligence, motivation, interests, and talents). On the other hand, external factors incorporate family environmental factors (parents' attention, home or family atmosphere, and economic conditions), university factors (lecturers or instructors, practical tools, supporting books, and workshop conditions), and community factors (peers, community activities, and neighborhood). Additionally, 
according to Mokhtar, Yusof, \& Misiran (2012), the obstacles in mathematics are often triggered by inadequate skills of Math. Based on the expert opinions above, it can be concluded that the learning difficulties factors can be divided into internal and external factors. The internal factors come from the students themselves and are very dependent on the development of their brain function, while the external factors are influenced by the students' environmental, such as family, school and the surrounding community.

Previous studies have identified many factors causing students learning difficulties in Mathematics. The findings from Astuti \& Sari (2018) indicated that the factors prompt students difficulties in abstract algebra lectures are (1) difficulties to understand the given problem that stimulate lack strategy to solve the problem; (2) lack of training on problem-solving; (3) lack of knowledge on the previous concepts; (4) monotonous teaching strategies that decrease students motivation in learning abstract algebra; (5) lack of lecturers' attention to students; (6) low teachers' capability. It means that the students' low ability on problem-solving strategy and the previous concept of the material can be categorized as the internal factor since it is within the students itself. On the other hand, lack of materials on problem-solving problems, the monotonous teaching strategies, the low teacher attention, and teacher competency can be included in the external factor since it is influenced by the surrounding environment of the students.

In addition, the study from Mundia (2012) highlighted that there were five main factors causing student learning difficulties, namely (1) students' negative perceptions towards mathematics; (2) unsatisfactory learning outcomes; (3) evaluation procedures on students; (4) specific learning disability in mathematics; and (5) lack of learning sources due to students' economy background. The students' negative perceptions of the difficulty of mathematics are affecting their negative attitudes toward mathematics. Many clarified that students' attitude plays an important role in mathematics learning process (Zan \& Di Martino, 2007; Gitaari et al, 2013). As reinforced by Githua \& Gowland (2003), the quality of textbooks, students' negative attitudes toward mathematics and inappropriate teaching methods have been the root problems of students' low achievement in the Nairobi and Rift Valley provinces, Kenya. The students' attitude toward mathematics can be categorized as the internal factor of learning difficulties.

Meanwhile, Enu, Agyman, \& Nkum (2015) examined the factors causing Mathematics learning difficulties among students in educational universities of Ghana that focus on students' personal factors and school factors. The students' factors consist of entry behavior, motivation, and attitude. On the other hand, the school factors include availability and use of learning materials, school type and teacher characteristics. Enu, Agyman, \& Nkum (2015) found that students' personal factors can be categorized as the internal factor of learning difficulties, while the school factors as the external factor. Besides, the external factors are also known as determining factors in mathematics learning. Mbugua, Kibet, Mutha, \& Nkonke (2012) reported the findings of Chepchieng (1995) that student achievement in secondary schools is strongly related to the availability of qualified textbooks. They also reveal that understaffing, inadequate teaching materials, low motivation, and negative attitudes from both teachers and 
students were the main factors that led to low students' achievement in Mathematics. Meanwhile, the research results from Gafoor \& Kurukkan (2015) clarified that students' lack of effort and prerequisites materials have been the main cause of students' difficulties in mathematics. In addition, students' low attention and motivation during the learning process also contribute to their learning problems.

From the related literature, the factors that cause learning difficulties as the focus of this study are classified into two, i.e. the internal factors consisting of students' attitudes toward abstract algebra courses, motivation, and prior knowledge, while, the external factors including lecturer performance, learning method, and learning materials. Ma \& Kishor (1997) defined attitudes towards mathematics as a student's preference or the tendency to avoid or to contribute to mathematics learning activities, and the belief whether mathematics beneficial or not. Furthermore, Ma \& Kishor (1997) pointed out that a positive attitude towards mathematics plays a significant role in every level of education. Furthermore, Acharya (2017) explained that motivation directly affects students' involvement during mathematics learning. Meanwhile, the prior knowledge is defined by Acharya (2017) as students' initial or prior knowledge possessed towards the content of mathematics.

The external factors in this study contain the lecturers' material mastery, their ability to explain the material to students (students' perceptions of the learning methods applied by the lecturer), and the available teaching materials to support abstract algebra learning. Based on the previous studies and the researchers' experience managing abstract algebra courses, many students find it difficult to understand the materials that impact on their low learning outcomes. This condition should be a concern for the lecturer to make sure the success of learning. To formulate the right strategy on the existing problems, it is necessary to clarify the factors that cause students learning difficulties as soon as possible. Actually, there are so many factors that can trigger learning difficulties among students but based on the literature review and previous research results, these factors can be divided into two categories, i.e. internal and external factors. The internal factors that are often considered to cause the learning difficulties include student's attitudes, learning motivation, and student's prior knowledge. Meanwhile, the external factors consist of lecture's performance, learning methods, and teaching materials. It underlines the factors causing learning difficulties in this study involve these two factors, namely the internal and the external factors.

This study aims to describe the dominant factors causing the students' difficulties in learning abstract algebra. The dominant factors that cause learning difficulties reviewed in this study consist of the internal factors (student attitudes toward abstract algebra courses, motivation, and student's prior knowledge) and the external factors (teacher performance, learning method, and teaching materials).

\section{METHOD}

\section{Research Design}

It was a descriptive research using survey method. A descriptive research tries to describe a phenomenon as it is without imposing any treatment to the phenomenon 
(Ditjen PMPTK, 2008), while survey is a method to collect the information of dominant factors causing the students' difficulties in learning abstract algebra.

\section{Participants}

The research participants were the entire sixth-semester students of mathematics education department of Riau Kepulauan University, Indonesia in the academic year of 2016/2017 consisting of 30 students. All participants had taken abstract algebra courses and they were believed to be able to provide information about the obstacles faced in learning this course. The sampling technique uses saturation sampling where all members of the population were used as the research samples.

\section{Instrument and Procedures}

The instruments used in this study were the questionnaire and the interview guidelines. Questionnaire used in this research adopted a previous research conducted by Saputra, Subagsono, \& Rohman (2012) and Enu, Agyman, \& Nkum (2015). To obtain initial data about the factors causing students' difficulties in learning abstract algebra, the questionnaire was distributed to students. The questionnaire was a closed-type with 5 Likert scales (strongly agree, agree, neutral, disagree, strongly disagree). The factors that caused students' learning difficulties consisted of two factors, namely the internal and the external factors. The internal factors consisted of attitude, motivation, and prior knowledge on abstract algebra subjects, while the external factors referred to lecturer performance, learning methods, and teaching materials. The questionnaire guidelines can be seen in Table 2 .

\section{Table 2}

Questionnaire guidelines

\begin{tabular}{lll}
\hline Factor Type & Indicators & Sub-indicators \\
\hline Internal & Attitude towards & Student interest \\
& abstract algebra & Student attention \\
& courses & Students' perceptions of abstract algebra courses \\
\cline { 2 - 3 } & Motivation & Learning spirit \\
& Learning perseverance \\
& Students' readiness to participate in learning \\
& Students' enthusiasm to participate in learning \\
\cline { 2 - 3 } & Prior Knowledge & Concept mastery of matrix \\
& & Concept mastery of numbers relations \\
& & Concept mastery of function \\
& Concept mastery of division and concordance of integers \\
\hline External & Lecturer & Lecturers' material mastery \\
& performance & Lecturers' teaching competency \\
\cline { 2 - 3 } & Learning method & Lecturers' teaching methods to support students' material \\
& & understanding \\
\cline { 2 - 3 } & Teaching & Availability of learning resources \\
& materials & Variation of learning resources \\
\hline
\end{tabular}

The interview was conducted to gain deeper information on the factors that cause students' difficulties in abstract algebra learning by using a semi-structured method. It 
used interview guidelines that were more flexible than structured models. The interview guidelines were prepared based on the statements in the questionnaire but the researcher can develop questions according to the information need. The respondents were chosen referring to the required information related to the research agenda. They were chosen randomly from respondents who admitted to having difficulty in abstract algebra learning based on the questionnaire results.

\section{Data Analysis Technique}

The data of students' responses to the questionnaire were then analyzed by calculating the percentage of responses to the available options. Positive responses were represented by the strongly agree and agree options, while the negative responses were represented by disagree and strongly disagree options (Leong, 2013; Enu, Agyman, \& Nkum, 2015). The percentage was then categorized as the causing factors of the students' difficulties referring to categories presented in Table 3 (Ferryansyah et al, 2018).

Table 3

Category of the learning difficulties cause

\begin{tabular}{ll}
\hline Score Percentage Interval & Category \\
\hline $81-100$ & Very weak \\
\hline $61-80$ & Weak \\
\hline $41-60$ & Fair \\
\hline $21-40$ & Strong \\
\hline $0-20$ & Very strong \\
\hline
\end{tabular}

After collecting the data from questionnaire, then we conducted interviews to clarify the students' responses. After that, we could draw a conclusion about the dominant factors causing the students difficulties in learning abstract algebra.

\section{FINDINGS}

Based on the questionnaire results, we got percentages of the factors causing students' learning difficulties in abstract algebra. The result is presented in Table 4. 
Table 4

The analysis of questionnaire results on the factors causing students' difficulties in learning abstract algebra courses

\begin{tabular}{|c|c|c|c|c|c|c|c|c|c|c|}
\hline \multirow{2}{*}{ Factors } & \multirow{2}{*}{ Indicators } & \multirow{2}{*}{ Statements } & \multirow{2}{*}{ Type } & SA & $\mathrm{A}$ & $\mathrm{N}$ & $\mathrm{D}$ & SD & Percentage & \multirow{2}{*}{$\begin{array}{l}\text { Mean } \\
\%\end{array}$} \\
\hline & & & & f & $\mathrm{f}$ & f & f & $\mathrm{f}$ & & \\
\hline \multirow[t]{14}{*}{ Internal } & \multirow{5}{*}{$\begin{array}{l}\text { Attitude } \\
\text { towards } \\
\text { abstract } \\
\text { algebra }\end{array}$} & I like abstract algebra courses. & + & 2 & 10 & 18 & 0 & 0 & 40 & \multirow[t]{5}{*}{36.7} \\
\hline & & $\begin{array}{l}\text { I pay full attention of the lecturers' } \\
\text { explanation on abstract algebra } \\
\text { material. }\end{array}$ & + & 3 & 16 & 10 & 1 & 0 & 63.4 & \\
\hline & & $\begin{array}{l}\text { I am glad if the lecturer is absent or } \\
\text { there is no class on abstract algebra } \\
\text { lectures }\end{array}$ & - & 2 & 4 & 17 & 5 & 2 & 23.4 & \\
\hline & & $\begin{array}{l}\text { Abstract algebra courses are difficult } \\
\text { to understand. }\end{array}$ & - & 7 & 8 & 11 & 4 & 0 & 13.4 & \\
\hline & & $\begin{array}{l}\text { I chat with friends when the lecturer } \\
\text { explains abstract algebra materials. }\end{array}$ & - & 2 & 3 & 12 & 8 & 5 & 43.4 & \\
\hline & \multirow[t]{5}{*}{ Motivation } & $\begin{array}{l}\text { I easily give up when I face } \\
\text { difficulty in abstract algebra } \\
\text { lectures. }\end{array}$ & - & 2 & 4 & 12 & 9 & 3 & 40 & \multirow[t]{2}{*}{45.4} \\
\hline & & $\begin{array}{l}\text { I always try to be on time for } \\
\text { abstract algebra class. }\end{array}$ & + & 7 & 13 & 7 & 3 & 0 & 66.7 & \\
\hline & & $\begin{array}{l}\text { I ask questions to the lecturer when I } \\
\text { do not understand abstract algebra } \\
\text { material }\end{array}$ & + & 0 & 10 & 19 & 1 & 0 & 33.4 & \\
\hline & & $\begin{array}{l}\text { I learn abstract algebra material by } \\
\text { myself at home. }\end{array}$ & + & 0 & 5 & 13 & 10 & 2 & 16.7 & \\
\hline & & $\begin{array}{l}\text { I try to complete every abstract } \\
\text { algebra assignment well. }\end{array}$ & + & 5 & 16 & 9 & 0 & 0 & 70 & \\
\hline & \multirow{4}{*}{$\begin{array}{l}\text { Prior } \\
\text { knowledge } \\
\text { of students }\end{array}$} & $\begin{array}{l}\text { I find it difficult to understand the } \\
\text { matrix concept. }\end{array}$ & - & 0 & 6 & 11 & 13 & 0 & 43.4 & \multirow[t]{4}{*}{28.4} \\
\hline & & $\begin{array}{l}\text { I easily understand the concept of a } \\
\text { set of numbers. }\end{array}$ & + & 0 & 9 & 17 & 4 & 0 & 30 & \\
\hline & & $\begin{array}{l}\text { It is easy for me to prove the nature } \\
\text { of the injective, surjective, and } \\
\text { objective functions. }\end{array}$ & + & 1 & 4 & 20 & 5 & 0 & 16.7 & \\
\hline & & $\begin{array}{l}\text { I find it difficult to understand the } \\
\text { concepts of division and } \\
\text { concordance in integers. }\end{array}$ & - & 0 & 8 & 15 & 7 & 0 & 23.4 & \\
\hline \multirow[t]{6}{*}{ External } & \multirow[t]{2}{*}{$\begin{array}{l}\text { Lecturer } \\
\text { performance }\end{array}$} & $\begin{array}{l}\text { The lecturers of abstract algebra are } \\
\text { able to explain the material well. }\end{array}$ & + & 15 & 9 & 6 & 0 & 0 & 80 & \multirow[t]{2}{*}{56.7} \\
\hline & & $\begin{array}{l}\text { The material explanation from the } \\
\text { lecturer is too fast so I am not able } \\
\text { to grasp it. }\end{array}$ & - & 4 & 7 & 9 & 8 & 2 & 33.4 & \\
\hline & \multirow[t]{2}{*}{$\begin{array}{l}\text { Learning } \\
\text { method }\end{array}$} & $\begin{array}{l}\text { The teaching method from the } \\
\text { lecturer makes it easier to } \\
\text { understand abstract algebra material. }\end{array}$ & + & 2 & 9 & 15 & 4 & 0 & 36.7 & \multirow[t]{2}{*}{43.4} \\
\hline & & $\begin{array}{l}\text { The teaching method is monotonous } \\
\text { so I get bored. }\end{array}$ & - & 0 & 6 & 9 & 12 & 3 & 50 & \\
\hline & \multirow[t]{2}{*}{$\begin{array}{l}\text { Teaching } \\
\text { materials }\end{array}$} & $\begin{array}{l}\text { I find it difficult to comprehend } \\
\text { abstract algebra reference books } \\
\text { used in lectures. }\end{array}$ & - & 5 & 6 & 10 & 9 & 0 & 30 & \multirow[t]{2}{*}{23.4} \\
\hline & & $\begin{array}{l}\text { I have other learning resources on } \\
\text { abstract algebra besides those given } \\
\text { by lecturers. }\end{array}$ & + & 0 & 5 & 10 & 14 & 1 & 16.7 & \\
\hline
\end{tabular}

International Journal of Instruction, January 2021 •Vol.14, No.1 
Based on the questionnaire analysis results in Table 4, there are three dominant factors causing the learning difficulties with strong category, the attitude towards abstract algebra, prior knowledge, and teaching material. Meanwhile, the other three factors are in fair category, motivation, lecturer performance, and learning method. The analysis results of the questionnaire could also be seen in Figure 1.

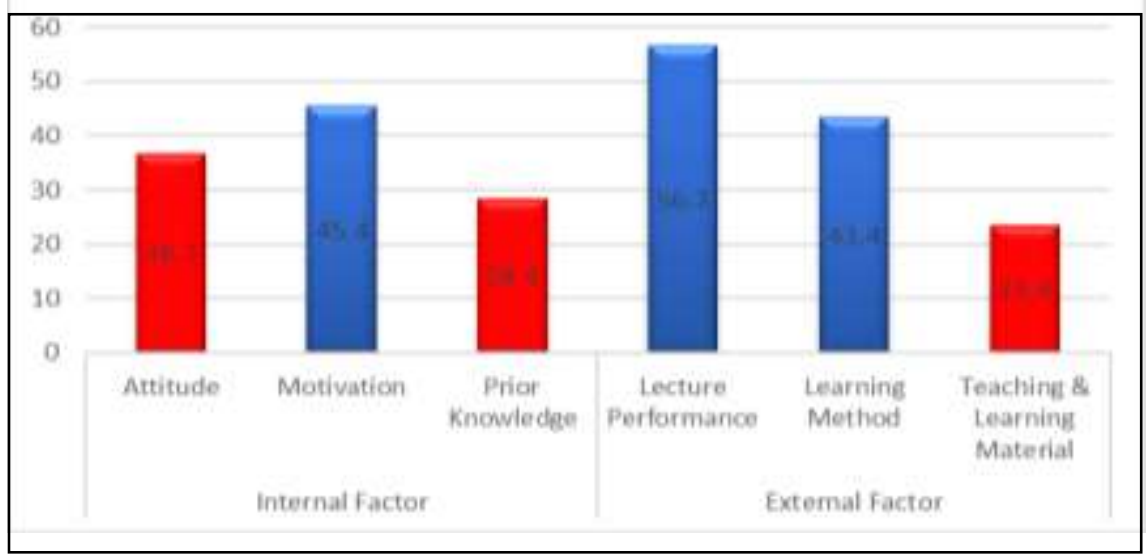

Figure 1

Percentage of the questionnaire results

The red parts in Figure 1 represent the dominant factors with strong category, while the blue parts represent the factors with fair category. Furthermore, we provided a discussion on each dominant factor based on the results of questionnaires and interviews.

\section{Students' Attitude towards Abstract Algebra}

Students' positive attitude on mathematics gives a significant impact on math learning in all education levels (Ma \& Kishor, 1997). It is important to develop a positive attitude towards mathematics because there is a direct correlation between students' attitudes and their learning outcomes (Bilican, Demirtasli, \& Kilmen, 2011; Chiesi \& Primi, 2009; Lipnevich, Maccann, Krumm, Burrus, \& Roberts, 2011; Marchis, 2011). In this study, there were four statement for the factor of students' attitude towards abstract algebra. Two of them had very low percentage, namely the third statement (13.4\%) and the fourth statement $(23.4 \%)$.

The fourth statement said "Abstract algebra courses are difficult to understand". The students' responses to this statement shows that most of the students still consider that abstract algebra is difficult to understand. To support the data, an interview session was conducted with 6 students which consist of high, moderate, and low ability.

According to the interview results, it was revealed that most students expressed difficulties in learning abstract algebra. It was caused by several things. Most of the students admitted that abstract algebra was a relatively new material for them or they never learned it before. So, many terms were unfamiliar. The abstract concept made 
them having more difficulties. A lot of unfamiliar terms as well as of theorems proofs placed them in difficult situations to practice their reasoning abilities. They did not feel comfortable and familiar with axiomatic proofing methods. The material structure in abstract algebra was determined by its certain properties that made it difficult to be understood. The connected relationship from the previous concepts also made the students experiencing problems if they did not grasp the previous concept. It is consistent with Harel (in Findell, 2001) that abstract algebra considered difficult among students because of its nature of concepts, such as abstract structures, objects properties, and properties rather than its primary examples. Furthermore, the number of examples and the use of axiomatic methods in proofing that are unfamiliar for students also cause difficulties.

Meanwhile, the third statement of "I am glad if the lecturer is absent or there is no class on abstract algebra lectures", obtained the percentage of $23.4 \%$ or only seven students were unhappy if the lecturer was absent. Based on the interview results, one of the respondents stated that they were happy if the lecturer was unable to attend the class and they felt free from the burden of learning as follows.

"I feel stressed during classroom learning because the material is very difficult to understand. If there is no class it was such a relief. Though, I realize that it will make me left behind in case of material and I can easily forget when I do not study it in a quite long time."

The above statement shows that the students were less attracted to learning and still have negative perception to abstract algebra. Furthermore, the average of percentage got $36.72 \%$ showing that the students' attitude towards abstract algebra becomes the dominant factor causing learning difficulties with strong category.

\section{Learning Motivation}

The students' low motivation will directly influence learning outcomes. Moreover, in university level, the face to face learning with the lecturer was very limited and it was impossible for lecturers to repeat the same material to the students. If there was no feedback from students, it can make the situation getting worse. It is consistent with the statement from Enu, Agyman, \& Nkum (2015) that "a highly motivated person puts in the maximum effort in his or her job". Furthermore, Acharya (2017) explains that motivation is one of the key factors affecting the bad result in mathematics learning. Motivation has been an internal and external factor that stimulates the willingness and perseverance to maintain interest and commitment to learning something. Gafoor \& Kurukkan (2015) also express that students' lack of attempt and qualifications are the main cause of which mathematics becoming a tough subject for students.

Based on the questionnaire data, only 5 of 30 respondents stated that they learn abstract algebra material at home. In other words, students' efforts to study were still low. During the interview session, the students said that the material difficulty level made them lazy to learn so they decided to directly ask the lecturers in the learning process. The following is the statement from one of the respondent: 
"When I comprehend the material little bit, it makes me curious to try the task and discusses with a friend, but if I find the problem complicated at the beginning, usually, I immediately give up."

Meanwhile, some students admitted that they did not have time to study at home because of various activities. Even from the interview results, there were respondents who mentioned that he preferred to hang out with a friend if they have free time or holidays. He only studied when he got his turn to perform presentation or to face an exam. It indicated that students had not been able to manage their time well and have low learning passion. Also, several students are shy to ask lecturers questions if they do not understand the material of abstract algebra. It can be seen from the questionnaire analysis with a percentage of 33.4. It means that the students' motivation to ask questions is still low and causes learning difficulties in abstract algebra.

In contrast, the 10th statement (I try to complete each abstract algebra task well) had the highest achievement percentage of $70 \%$. As many as 21 students agreed that they tried to do the given assignments by the lecturers based on their ability. Here, one of the respondent stated:

"If there is an abstract algebra assignment, I will try to do it well and on time. By doing so, I can improve my exam scores. In the assignments, the lecturers usually allow having discussions with friends so I try my best to do it. "

It shows that the students' motivation in learning abstract algebra still needs to be improved. However, the motivation indicators consisting of 5 statements gained the average achievement of $45.4 \%$ meaning that the indicator listed as the dominant factor causing student learning difficulties with fair category.

\section{Students Prior Knowledge}

Students' prior knowledge is an important component that supports student performance in learning. According to Ali (2011), prior knowledge of primary concepts provides a foundation upon which learning of subsequent concepts. Abstract algebra which is deductive in nature and involves a lot of basic mathematical concepts such as numbers, functions, division, matrix, and so on requires students to master these concepts. In studying abstract algebra, understanding the number system can be very helpful. However, based on questionnaire results, students still experienced difficulties regarding the pre-requisite material especially on the concept of a set of relations of numbers, the nature of the injective, surjective and wise functions, and the concepts of the division and concordance of integers.

The indicator of prior knowledge gained an average achievement of $28.4 \%$ meaning that this indicator was one of the factors causing students to experience difficulties in abstract algebra learning with strong category. Meanwhile, from the interview results, it was revealed that the students did not really understand the prerequisite material, such as matrix, set, function, division, and concordance since they did not learn well at the previous level. As a result, lecturers often repeat the pre-requisite material before explaining the core part of abstract algebra material. In addition, the students were often 
confused when trying to identify the characteristics of groups and rings in the set of numbers and matrix. Regarding the importance of prior knowledge in mathematics learning, Acharya (2017) states that the fundamental comprehension of mathematics at the secondary level is a key that determines student performance in further studies. The research results by Retnawati et al, (2017) also show that the lack of fundamental understanding of mathematics causing the low students' performance in mathematics. Gafoor \& Kurukkan (2015) also urge that students' lack of effort and prerequisites are the major reasons why mathematics being a difficult subject for students.

\section{Lecturer Performance}

Based on the questionnaire result analysis, lecture performance becomes one of the dominant factors causing learning difficulties of abstract algebra with fair category and percentage of $56.7 \%$. A teacher is a person who provides education for students individually and motivates for teaching-learning activities. The positive attitude of the teacher creates a positive direction for students for learning mathematics (Acharya, 2017; Marchis, 2011; Sakiz, Pape, \& Hoy, 2012). In contrast, (Saputra, Subagsono, \& Rohman, 2012) points out that the unclear teacher explanation and the use of inappropriate methods can create learning difficulties. The questionnaire result indicated that lecturers of abstract algebra courses were able to explain the material well, i.e. $80 \%$ of students agreed with the statement. However, $36.7 \%$ of students stated that the material presented was still too fast so they could not grasp the material properly. The following are excerpts from interviews with respondents who gave negative responses.

"The material from lecturers can be comprehended if they explain at a slow pace because I am among those who are slow in understanding abstract algebra material. There is sometimes an unfinished explanation due to the running out of time, only half of the whole procedures are explained, while the rest should be continued by students themselves. It is hard for me because I can not study alone. Moreover, it is very difficult to meet with peers outside the class hour to have discussions. "

Another respondent mentions:

"In case of the difficult material, there are some unfamiliar terms that I do not understand and it makes me unable to understand the lecturers' explanations well. For example, I have not memorized exactly what is meant by identity elements, unity elements, inverses, groups, subgroups, normal groups, subgroups, homeomorphisms, etc."

Based on the interview results, there are many mathematical terms in abstract algebra that are relatively new for students and it makes them confused about the meaning of these terms. It disturbs their comprehension process because what the lecturer says cannot be digested by the students. In order to make a confirmation, the researchers also interviewed students who gave positive responses. In general, they mentioned that the lecturers' explanation was understandable but sometimes was too fast. It indicates the students' ability is diverse, some are fast and others are slow in understanding the material. Thus, the lecturer must improve his/her strategy in performing material delivery such that the students could understand his explanation. 


\section{Learning Method}

For the learning method factor, $63.4 \%$ of students disagreed that the teaching method makes them easier to understand abstract algebra material. It means that the learning method used still prevents the students to understand the material. From the interview, we got information that learning methods often used in abstract algebra are group discussion and expository method. The lecturers provided opportunities for the students to explore their abilities and to present material to other groups. The discussion took place during the question and answer session. The role of the lecturer as a facilitator and providing material affirmation if there was a mistake made by the student. For the difficult material, the lecturer applied the expository method in which the lecturer explained the material, at first, then gave the students the practical questions. In this method, the lecturer also provided an opportunity for the students to discuss with peers and to have question and answer sessions so that they can learn from one another. The difficulties experienced by the students with low learning preparation and those who lack understanding of the previous material. During the presentation carried out by a group of students who did not understand the material, other students would also found some difficulties. This condition made them unable to grasp the material well. The following is one excerpt from the interviews with respondents who stated that the learning methods applied by the lecturer were appropriate.

"After the lecturer explaination and group presentation, I can understand the content. I think the collaborative learning method implemented by the lecturer is effective since it promotes student independence in learning. But, maybe, the preparation of the students themselves is not really good. I usually ask questions on what I had not understood as well as to make other students learn more about the material. With the material reinforcement and clarification on students' mistakes, I can grasp the content of the material. So, in my opinion, no problem with the learning method and indeed it has been proper with the learning model at the university level that emphasizes the students' autonomous learning. The key point is how students prepare themselves to learn and show their best during the presentation. "

Referring to the obtained information, the lecturers must immediately take anticipation steps so that learning can run effectively. This is in line with Zaffar, Quraishi, \& Ansari (2009) that learning method plays an important role to the students' success in learning. His view said that a good lecture must be clear, systematic, complete and precise. Therefore, a lecture has to be able to plan his learning appropriately and effectively to fulfil the need of the students. The percentage of the learning method factor is $43.4 \%$. Thus, it categorized as dominant factor with fair category.

\section{Teaching Materials}

The external factors that cause learning difficulty of further abstract algebra are on the availability of teaching materials. The questionnaire result indicates that teaching materials indicator as one of the factors causing student learning difficulties with strong category $(23.4 \%)$. There were $70 \%$ students stated that they found difficulties to 
understand the reference books used in abstract algebra courses. Furthermore, $16.7 \%$ of students admitted that they had other learning resources besides those given by lecturers.

Meanwhile, the interviews showed that the information was understandable if the main learning resources during the learning were textbooks. However, the textbooks were old publications and, according to the students, the language was too rigid and difficult to be comprehended. There were many symbols and the preparation of theorem-proof was not well-arranged. Also, the examples of problems and solutions were sometimes not given in detail at the beginning so that students with less initial knowledge found it difficult to understand. Enu, Agyman, \& Nkum (2015) underlines that the availability, provision and the use of learning materials are so important that enhances students' academic performance. It is supported by Akkoyunlu (2002) who state that instructional materials motivate students, and encourage them to study lesson as well as provide them with the opportunity to have information to evaluate it.

\section{DISCUSSION}

The analysis results showed that three out of six dominant factors causing difficulties of abstract algebra learning were included in the strong category, and the other three were in the fair category. The three strong factors are students' attitudes towards abstract algebra, prior knowledge, and learning materials, while the fair factors are motivation, lecturer performance, and learning method. After conducting interviews with students, it was also revealed that the internal factors that came within the students were reflected by their perception of the difficulty of abstract algebra courses, low learning motivation, and inadequate prior knowledge. Meanwhile, the external factors are the lack of learning resources that can support students to comprehend the material easily and to facilitate self-regulated learning. This finding is in accordance with Mbugua, Kibet, Mutha, \& Nkonke (2012) that contributing factors to poor mathematics performance include understaffing, inadequate teaching materials, low motivation and poor attitudes by both teachers and students.

After knowing the factors that cause student learning difficulties, a strategy is required to overcome the existing problems. To solve the problem of many students who think that abstract algebra is a difficult subject, the lecturer should try to instill a positive attitude in lectures, for example being more friendly to students, fostering mutual help in learning, and giving appreciation to active students although his/her works or answers still incorrect. As stated by Fisher \& Rickards (1998), students' attitudes towards mathematics tended to be more positive in classroom where students perceived better leadership models and friendly behaviors from their teachers, on contrary it can be more negative if the teachers are unfriendly and have strict behaviors.

Furthermore, the factor of motivation also needs attention from the lecturer. The low motivation could impact on the weak effort of the students and their readiness to learn. Therefore, lecturer needs to actively improve the students' motivation. According to Retnawati et al (2017), increasing the motivation of learning can be enhanced through improvements of mathematics teaching and learning in the classroom. Besides improving motivation, it could also improve learning quality and students' 
understanding. It demands the lecturers to improve their skills in teaching, using innovative learning models, and supporting their students' concept understanding. To support students' understanding, a lecturer could use leveling exercises, from the simple to the complex problems such that the students' learning motivation fostered. Lecturer could also apply active learning by facilitating group discussion to enable the students collaborate to create conducive learning environment. This is in line with Hackathorn, Solomon, \& Blankmeyer (2011) who said that active learning impacts on the higher levels of learning (analysis, evaluation, and creation). Besides, active learning could be applied to a class with diverse learning styles.

The factor that causes learning difficulties from the students' internal factors is their prior knowledge. Ali (2011) states that students' prior knowledge leads to a vital factor in facilitating in-depth learning. To support the initial knowledge among the student, lecturers can provide a little introduction to the prerequisite material before delivering the core material. They can give questions that build students' memories about previous concepts. Various learning strategies can also be applied to help students connect to the material the prerequisite material. This is in line with the statement from (Yeo, 2009; McLaren, 2010) that teachers' central role in promoting deeper learning requires them to understand and practice some of the basic principles in mathematics conceptual learning.

Another factor of students' learning difficulties is on the teaching materials. The results of the study show that the learning resources used by the lecturers in the form of old printed books whose language was difficult to understand. It causes students having inadequate learning resources to study independently. According to Mbugua (2011), Mathematics textbooks can be the second most powerful tool of teaching and learning Mathematics instead of the board. As the crucial role of the textbook in learning, a teacher or lecturer must understand well the way to write a proper book. Mohammad \& Kumari (2007) explain that textbook writers and editors have a huge responsibility to ensure clarity of language, adequate information, and minimal errors or typos. In addition, they should also ensure that the textbook provides adequate methodological guidance and input to the teachers. It includes the suggestion of effective ways to teach the content, specify the foundation of learning philosophy, describe the achievement outcomes of the proposed methods, propose appropriate methods for assessment and ensure the link between teaching and assessment methods. It shows that the lecturer's task is to provide textbooks or compile their own textbooks that are in accordance with the students' characteristics so it can support and facilitate students to learn independently.

\section{CONCLUSION}

According to the research results, it can be concluded that the dominant factors that cause students difficulties of abstract algebra learning in strong category consisting of students' attitudes towards abstract algebra, lack of prior knowledge, and inadequate teaching materials with the percentage on each factor were $36.7 \%, 28.4 \%$, and $23.4 \%$ respectively as the strong category. The other three factors, namely motivation, lecturer performance, and learning methods include the factors that cause students' learning 
difficulties in abstract algebra with the fair category with $45.4 \%, 56.7 \%$, and $43.4 \%$ respectively.

\section{RECOMMENDATIONS}

Referring to the findings, it can be suggested that lecturers as a central role in learning should apply active and innovative learning methods to foster students' motivation and positive attitudes toward abstract algebra courses. Furthermore, to strengthen the students' prior knowledge, lecturer needs to do apperception recalling the pre-requisite materials needed to learn the new concepts. Meanwhile, for the lack of learning material, lecturer needs to develop their own textbooks in accordance with the students' characteristics and based on the principles of good teaching materials. The textbooks should be able to facilitate students to study independently as well as to support the strengthening of the concepts from prior knowledge that is required to study the core material

\section{ACKNOWLEDGEMENT}

We would like to express our sincere gratitude for the Ministry of Research, Technology and Higher Education of Indonesia who has supported this study through the scheme of Penelitian Kerjasama Antar Perguruan Tinggi (PKPT) [Collaborative Research in Higher Education] in the funding year of 2018 with the research contract agreement No. 01/KP-PKPT/LPPM/UNRIKA/IV/2018.

\section{REFERENCES}

Acharya, B. R. (2017). Factors affecting difficulties in learning mathematics by mathematics learners. International Journal of Elementary Education, 6(2), 8-15. https://doi.org/10.11648/j.ijeedu.20170602.11

Agustyaningrum, N., Abadi, A.M., Sari, R.N., \& Mahmudi, A. (2018). An analysis of students' errors in solving abstract algebra tasks. Journal of Physics: Conf. Series, 1097 (2018) 012118, 1-12. https://doi.org/10.1088/1742-6596/1097/1/012118

Agustyaningrum, N., Hanggara, Y., Husna, A., Abadi, A. M., \& Mahmudi, A. (2019). An analysis of students' mathematical reasoning ability on abstract algebra course. International Journal of Scientific \& Technology Research, 8(12), 2800-2805.

Agustyaningrum, N., Hanggara, Y., Husna, A., Abadi, A. M., \& Mahmudi, A. (2020). Analysis of mathematical proof ability in abstract algebra course. Universal Journal of Educational Research, 8(3), 823-834. https://doi.org/10.13189/ujer.2020.080313

Akkoyunlu, B. (2002). Educational technology in Turkey: past, present, and future. Educational Media International, 2(39), 165-174. https://doi.org/10.1080/09523980210155352

Ali, T. (2011). Exploring students' learning difficulties in a secondary mathematics classroom in Gilgit-Baltistan and teachers' effort to help students overcome these difficulties. Bulletin of Education and Research, 33(1), 47-69. https://doi.org/10.1016/j.sbspro.2013.10.243 
Arikan, Elif E., Ozkan, A and Ozkan E M. (2015). An examination in turkey: error analysis of mathematics students on group theory. Educational Research and Reviews. 10(16), 2352-2361. https://doi.org/10.5897/ERR2015.2329

Astuti \& Sari, H. (2018). Analisis kesulitan belajar struktur aljabar di STKIP Pahlawan Tuanku Tambusai [An Analysis of the learning difficulty on the algebraic structure in STKIP Pahlawan Tuanku Tambusai]. Jurnal Pendidikan Matematika. 12(2), 73-80. https://doi.org/10.22342/jpm.12.2.4142.73-80

Bilican, S., Demirtasli, R. N., \& Kilmen, S. (2011). The attitudes and opinions of the students towards mathematics course: The comparison of TIMSS 1999 and TIMSS 2007. Educational Sciences: Theory \& Practice, 11(3), 1277-1284. Retrieved from https://files.eric.ed.gov > Fulltext

Chiesi, F., \& Primi, C. (2009). Assessing statistics attitudes among college students: Psychometric properties of the Italian version of the Survey of Attitudes towards Statistics (SATS). Learning and Individual Differences, 19(2). 309-313. https://doi.org/10.1016/j.lindif.2008.10.008

Clark, Allan. (1984). Elements of Abstract Algebra. New York: Dover Publications, Inc.

Ditjen PMPTK. (2008). Pendekatan, jenis, dan metode penelitian Pendidikan [Approaches, types, and methods of educational research]. Jakarta: Ministry of National Education of Indonesia.

Enu, J., Agyman, O. K., \& Nkum, D. (2015). Factors influencing students' mathematics performance in some selected colleges of education in Ghana. International Journal of Education Learning and Development, 3(3), 68-74.

Fadilah, S. \& Jamilah. (2016). Pengembangan bahan ajar struktur aljabar untuk meningkatkan kemampuan pembuktian matematis mahasiswa [Development of teaching materials in algebraic structure to improve students' mathematical proof abilities]. Jurnal Cakrawala Pendidikan, 35(1), 106-113. https://doi.org/10.21831/cp.v1i1.8379

Ferryansyah, Widyawati, E. \& Rahayu, S. W. (2018). The analysis of student's difficulty in learning linear algebra. IOP Conf. Series: Journal of Physics: Conf. Series. https://doi.org/10.1088/1742-6596/1028/1/012152

Findell, B. R. (2001). Learning and understanding in abstract algebra. Ph.D. Thesis, University of New Hampshire. Retrieved from https://pdfs.semanticscholar.org/9201/9bab4d780309d603325085d3aacd83a14582.pdf

Fisher, D. \& Rickards, T. (1998). Associations between teacher-student interpersonal behavior and student attitude towards mathematics. Mathematics Education Research Journal, $\quad$ 10(1), 3-15. Retrieved from http://citeseerx.ist.psu.edu/viewdoc/download?doi=10.1.1.588.6916\&rep=rep1\&type=pdf

Gafoor, K. A. \& Kurukkan, A. (2015). Learner and teacher's perception of difficulties in learning and teaching mathematics: some implications. Paper presented at the National Conference on Mathematics Teaching- Approaches and Challenges Sub-Theme: Challenges in inculcating mathematization abilities among learners. Regional Institute 
of Education, Mysuru, Karnataka, India. Retrieved from https://files.eric.ed.gov/fulltext/ED568368.pdf

Gallian, J. A. (2010). Contemporary Abstract Algebra, Seventh Edition. New York: Eddison Wesley Publishing Company.

Gitaari, E. M. E., Nyaga, G., Muthaa, G., \& Reche, G. (2013). Factors contributing to students' poor performance in mathematics in public secondary schools in Tharaka South District, Kenya. Journal of Education and Practice, 4(7), 93-100. https://doi.org/10.24297/ijrem.v10i0.7761

Githua, Bernard \& Gowland-Mwangi, John. (2003). Students' mathematics self-concept and motivation to learn mathematics: Relationship and gender differences among Kenya's secondary-school students in Nairobi and Rift Valley provinces. International Journal of Educational Development, 23, 487-499. https://doi.org/10.1016/S07380593(03)00025-7

Hackathorn, J., Solomon, E. D., \& Blankmeyer, K. L. (2011). Learning by doing: an empirical study of active teaching techniques. The Journal of Effective Teaching, 11(2), 40-54.

Haryono, J. K. \& Susanto, H. A. (2013). Meningkatkan aktifitas mahasiswa melalui pembelajaran berbasis masalah mata kuliah struktur aljabar. Paper presented at Seminar Nasional Matematika dan Pendidikan Matematika dengan tema "penguatan peran matematika dan pendidikan matematika untuk Indonesia yang lebih baik" [Improve student activities through problem-based learning of algebraic structure courses. Paper presented at the National Seminar on Mathematics and Mathematics Education with the theme "strengthening the role of mathematics and mathematics education for a better Indonesia"]. Yogyakarta, Universitas Negeri Yogyakarta. Retrieved from http://eprints.uny.ac.id/10768/1/P\%20-\%2045.pdf

Ikramuddin \& Quraisy, A. (2017). Identifikasi faktor-faktor penyebab kesulitan belajar mahasiswa pada mata kuliah struktur aljabar di Program Studi Pendidikan Matematika Universitas Muhammadiyah Makassar [Identification of factors that cause students learning difficulties in algebraic structure courses in the Mathematics Education Study Program, Muhammadiyah University, Makassar]. Nabla Dewantara: Jurnal Pendidikan Matematika, 2(2), 47-58.

Judson, T. W. (2015). Abstract algebra theory and application. Ann Arbor: Orthogonal Publishing L3C.

Karimah, R. K. N., Kusmayadi, T. A. \& Pramudya, I. (2018). Analysis of difficulties in mathematics learning on students with guardian personality type in problem-solving HOTS geometry test. IOP Conf. Series: Journal of Physics. https://doi.org/10.1088/1742-6596/1008/1/012076

Leon, K.E. (2013). Factors that influence the understanding of good mathematics teaching. Eurasia Journal of Mathematics, Science \& Technology Education, 9(3), 319328. 
Lipnevich, A. A., Maccann, C., Krumm, S., Burrus, J., \& Roberts, R. D. (2011). Mathematics attitudes and mathematics outcomes of U.S. and Belarusian middle school students. Journal of Educational Psychology, 103(1). 105-118. http://dx.doi.org/10.1037/a0021949

Listiawati, E. 2017. Proses kognitif mahasiswa calon guru dalam membuktikan grup ditinjau dari gaya kognitif [The cognitive process of prospective teacher in proving a group in terms of cognitive style]. SAINS, 17(1). 9-13. Retrieved from https://ejournal.uncen.ac.id/index.php/SAINS/article/view/14/11

Ma, X., \& Kishor, N. (1997). Assessing the relationship between attitude toward mathematics and achievement in mathematics: A meta-analysis. Journal for research in mathematics education, 28(1). 26-47. https://doi.org/10.2307/749662

McLaren, D. (2010). Does theory have any point? Mathematics in School, 29(5), 2-9.

Marchis, I. (2011). Factors that influence secondary school students' attitudes toward mathematics. Procedia Social and Behavioural Sciences, 29, 786-793. https://doi.org/10.1016/j.sbspro.2011.11.306

Mbugua, Z. K. (2011). Adequacy and the extent to which teaching and learning resources for mathematics are available and used for achievement in the subject in a secondary school in Kenya. American International Journal of Contemporary Research, 1(3), 112-116. Retrieved from https://pdfs.semanticscholar.org/3513/950410c3c814d8ffe57d09fd059db492f858.pdf?_ ga=2.97196058.441103564.1572869371-721226706.1572869371

Mbugua, Z. K., Kibet, K., Mutha, G. M., \& Nkonke, G. R. (2012). Factors contributing to students' poor performance in mathematics at Kenya certificate of secondary education in Kenya: a case of Baringo County, Kenya. American International Journal of Contemporary Research, 2(6), 87-91. Retrieved from https://www.aijcrnet.com/journals/Vol_2_No_6_June_2012/11.pdf

Mohammad, R. F \& Kumari, R. (2007). Effective use of textbooks: a neglected aspect of education in Pakistan. Journal of Education for International Development, 3(1), 1$12 . \quad$ Retrieved from https://pdfs.semanticscholar.org/5ec8/bbe3bd0ece4ff7e66b1ce478445a6879db4c.pdf

Mokhtar, S F., Yusof, Z Md. \& Misiran, M. (2012). Factors affecting students' performance in mathematics. Journal of Applied Sciences Research, 8(8), 4133-4137. Retrieved from http://www.aensiweb.com/old/jasr/jasr/2012/4133-4137.pdf

Mundia, L. (2012). The assessment of math learning difficulties in a primary grade-4 child with high support needs: a mixed-methods approach. International Electronic Journal of Elementary Education, 4(2), 347-366. Retrieved from https://files.eric.ed.gov/fulltext/EJ1070446.pdf

Retnawati, H., Kartowagiran, B., Arlinwibowo, J. \& Sulistyaningsih, E. (2017). Why are the mathematics national examination items difficult and what is teachers' strategy to 
overcome it? International Journal of Instruction, 10(3), 257-276. https://doi.org/10.12973/iji.2017.10317a

Sakiz, G., Pape, S. J., \& Hoy, A. W. (2012). Does perceived teacher affective support matter for middle school students in mathematics classrooms? Journal of School Psychology, 50(2), 235-255. https://doi.org/10.1016/j.jsp.2011.10.005

Saputra, A. E., Subagsono, \& Rohman, N. (2012). Faktor-faktor penyebab kesulitan belajar mahasiswa program studi pendidikan teknik mesin FKIP UNS pada mata kuliah praktik semester genap tahun akademik 2011/2012 [Factors that cause learning difficulties among students of Mechanical Engineering Education Study Program of Faculty of Teacher Training and Education Sciences UNS in practice courses in the academic year 2011/2012]. NOSEL, 1(1), 30-40. Retrieved from jurnal.fkip.uns.ac.id/index.php/ptm/article/download/1361/944

Syah, M. (2010). Psikologi Pendidikan [Educational Psycology]. Bandung, PT Remaja Rosdakarya. [Syah, M. (2010). Educational Psychology. Bandung, PT Remaja Rosdakarya, Indonesia]

Weber, K. (2002). Student difficulty in constructing proofs: the need for strategic knowledge. Educational Studies in Mathematics, 48, 101-119.

Weber, K., \& Larsen, S. (2008). Teaching and learning group theory. Making the Connection: Research and Teaching in Undergraduate Mathematics Education, (73), 137-149.

Yeo, Kai Kow J. (2009). Secondary 2 student difficult in solving non-routine problems. International Journal for Mathematics Teaching and Learning. Retrieved from https://www.google.com/url?sa=t\&rct=j\&q=\&esrc=s\&source=web\&cd=1\&ved=2ahUKEwj ZxP7H4M_kAhXKTX0KHZPBAEoQFjAAegQIBBAC\&url=http\%3A\%2F\%2Fwww.cimt.o rg.uk\%2Fjournal\%2Fyeo.pdf\&usg=AOvVaw2Y9JLFbh_p9iZC82n8r8na

Yuniati, S. (2014). Analisis kesalahan mahasiswa dalam menyelesaikan soal pembuktian pada matakuliah struktur aljabar [Analysis of student errors in solving proof problems in algebra structure subjects]. Jurnal Beta, 7(2). 72-81. Retrieved from https://jurnalbeta.ac.id/index.php/betaJTM/article/view/80/65

Zan, R., \& Di Martino, P. (2007). Attitude toward mathematics: Overcoming the positive/negative dichotomy. The Montana Mathematics Enthusiast, Monograph, 3, $157-168$.

Zaffar, A., Quraishi, A. M., \& Ansari, M. R. K. 2009. Teaching of Abstract Algebra at Undergraduate Level. The Sindh University Journal of Education, 39(10), 1-12. 